\title{
Whey Protein Isolate, Tween 20 and Casein Hydrolysate Stabilized O/W Nano-Vesicular Emulsion Systems with Curcumin Cargo
}

\author{
Soma Mukherjee ${ }^{1}$, Zee Haque ${ }^{2}$, Xue Zhang ${ }^{2} \&$ Wes Schilling ${ }^{2}$ \\ ${ }^{1}$ Department of Physical and Biomedical Science, University of Holy Cross, New Orleans, LA, 70131, USA \\ ${ }^{2}$ Department of Food Science, Nutrition and Health promotion, Mississippi State University, Mississippi State, \\ MS, 39762, USA \\ Correspondence: Soma Mukherjee, Department of Physical and Biomedical Science, University of Holy Cross, \\ New Orleans, LA, 70131, USA. E-mail: smukherjee@uhcno.edu
}

Received: August 13, 2021

Accepted: October 2, $2021 \quad$ Online Published: October 25, 2021

doi:10.5539/jfr.v10n5p48

URL: https://doi.org/10.5539/jfr.v10n5p48

\begin{abstract}
Stable oil-in-water nanoemulsions were generated by ultra-high-pressure homogenization (UHPH) at 140 and $210 \mathrm{MPa}$ for use as nano-vesicular vehicles (NVV) to carry hydrophobic generally recognized as safe (GRAS) curcumin (CU) by whey protein isolate (WPI) in aqueous nutraceutical systems. Curcumin was used for its antioxidant activity and participation in the Michael reaction with nucleophiles at $\mathrm{pHs}$ above 8.0. Two variables, (1) addition of casein hydrolysate (CH) (2\%, w/w of WPI) and, (2) use of UHPH (140 and $210 \mathrm{MPa})$, were studied for their effect on the stabilization of monodispersed NVV and antioxidant capacity of the CU as cargo in the NVV throughout storage. $\mathrm{CH}$ and Tween 20 both were added to increase dispersibility and stability of the NVV. Addition of $\mathrm{CH}$ reduced nano-particle size $\left(\mathrm{d}_{\mathrm{vs}}\right)$ by $17 \%$ at $210 \mathrm{MPa}$ when compared to140 $\mathrm{MPa}(\mathrm{P}<0.05)$, and increased the stability with UHPH pressure as reflected by a $63 \%$ smaller $\mathrm{d}_{\mathrm{vs}}$ at $210 \mathrm{MPa}$ as compared to 140 $\mathrm{MPa}(\mathrm{P}<0.05)$. The nanoparticle distribution was not changed by the addition of $\mathrm{CU}$, with $\mathrm{d}_{\mathrm{vs}}$ 's of 101 and $93 \mathrm{~nm}$ at $140 \mathrm{MPa}$ and 73 and 92 at $210 \mathrm{MPa}$ for NVV and CU-NVV, respectively. The NVV system was stable for 28 days as observed in zeta-potential, contact angle, and surface energy, and can be used to deliver CU and maintain its antioxidant activity.
\end{abstract}

Keywords: nanoemulsion, antioxidant, ultra-high-pressure homogenization (UHPH)

\section{Introduction}

Curcumin (CU) is used as a condiment and an herbal medicine in Asian countries for its nutraceutical properties (Chin et al., 2014). It is a diarylheptanoid in the form of a bright yellow-orange colored powder, with a high melting point $\left(183^{\circ} \mathrm{C}\right)$ that has been correlated with antioxidant (Sharma, 1976), anti-inflammatory (Chainani-Wu, 2003), anti-cancerous (Aggarwal et al., 2003), and antimicrobial (De et al., 2009) properties that were established in mouse studies. $\mathrm{CU}$ has also been linked to decreased incidence of depression, myelodysplastic syndrome and Alzheimer's (Tsai et al., 2011; Donsi et al., 2012; Ahmed et al., 2012; Alizadeh et al., 2012; Souguir et al., 2013; Aditya et al., 2017). However, metabolism and absorption research revealed that either no curcumin or a minute amount of curcumin was detected in tissue or blood serum after ingestion (Dhillon et al., 2008). The main constraints of delivering CU in foods includes poor solubility (Tonnesen et al., $2002)$ in water $(11 \mathrm{ng} / \mathrm{ml})$ and rapid hydrolysis at physiological $\mathrm{pH}$, which results in the formation of an inactive metabolic component. Delivery of CU in food-based emulsion systems is challenging due to its lack of solubility, instability, strong color, and distinct flavor (Yu and Huang, 2010; Shetty et al., 2015). The amount of curcumin that can be delivered without negatively impacting the taste, color and texture of the incorporated food is another important point of consideration when designing a delivery system. It has already been established that at levels less than $0.9 \mathrm{~g}$ /day CU ingestion and $20 \mathrm{mg}$ per serving causes no adverse effects (Nelson et al., 2017). A nano-emulsion system could be utilized to decrease the amount of CU that needs to be included in a food product to impart antioxidant capacity, while being acceptable to consumers.

Various phytochemical compounds (hydrophobic) have been delivered with accelerated release and rapid absorption using nanoemulsion systems (Zou et al., 2015). Nanoemulsions are made of extremely small droplets (average globule size of 100 to $500 \mathrm{~nm}$ ) of either water (water-in-oil, W/O) or oil (oil-in-water, O/W) systems, which form non-equilibrium, isotopically transparent dispersions that are stabilized by the addition of surfactant 
molecules to form an interfacial layer around the droplet (Lovelyn and Attama, 2011; Gutierrez et al., 2008). Nanoemulsions are optically transparent, physically stable, and have enhanced bulk viscosity. These characteristics are attributed to small droplets and a reduced particle size distribution (Donsi et al., 2012). However, nanoemulsions are not thermodynamically stable systems and tend to aggregate, which leads to sedimentation, coalescence, creaming and flocculation (Van de Ven et al., 2011). The generation of small and uniform sized dispersed phase droplets alleviates nanoemulsion instability (Kentish et al., 2008). Globular sizes of 20-200 nm create stable emulsion systems (Maali and Mosavian, 2013), with increasing stability as the globule diameter decreases (Pascual-Pineda et al., 2015). The emulsifier in the nanoemulsion system plays a critical role in forming a stable system.

Whey protein isolate (WPI) is used as an emulsifier in food grade emulsion systems due to its amphipathic nature (Adjonu et al., 2014; Chanamai and McClements, 2002; Euston et al., 2002). Whey protein's ability to form strong, cohesive protective films prevents emulsion droplet aggregation (Ramos et al., 2012). WPI has been used in nanoemulsion systems to deliver drugs that are not water-soluble (He et al., 2011), WPI-dextran conjugates (Fan et al., 2017), and lutein (Zhao et al., 2018).

The objectives of this study were to generate a nanoemulsion system using WPI as the emulsifier by UHPH and to evaluate its efficacy at delivering curcumin by measuring the particle size, zeta-potential, contact angle, surface energy, antioxidant activity and antioxidant persistence of the nanoemulsion.

\section{Materials and Methods}

Whey protein isolate (WPI) (Provon ${ }^{\circledR} 292$, Lot\# 0855701) was provided by Glanbia Nutritionals (Fitchburg WI). Peanut oil (Fresh salad oil, Great Value, Walmart, Benton, AR) was the dispersed phase. Curcumin (CU), (士)-6-Hydroxy-2,5, 7,8-tetramethylchromane-2-carboxylic acid (Trolox), the antioxidant standard Tween 20 (Polysorbate 20), 2,2'-Azobis(2-methylpropionamidine) dihydrochloride (ABAP), and chymotrypsin were acquired from Sigma-Aldrich (St. Louis, MO).

\subsection{Dialysis of WPI}

Forty grams of WPI was weighed and dispersed in $400 \mathrm{ml}$ of de-ionized (DI) water, followed by gentle stirring for $2 \mathrm{~h}$ using a magnetic stirrer at $20^{\circ} \mathrm{C}$, and the dispersed WPI was kept in dialysis tubing (50 ml per tubing). Four dialysis tubes were placed in a container with $4 \mathrm{~L}$ of deionized water, and dialysis of the entire volume of dispersed WPI was conducted in two batches. The containers with the tubing were stored at $4{ }^{\circ} \mathrm{C}$ with magnetic stirring and water and water was changed every $4 \mathrm{~h}$. Following the third change of water, WPI samples (which had undergone a 10,000 fold dialysis) were collected, freeze dried in a FreeZone ${ }^{\circledR}$ Triad ${ }^{\mathrm{TM}}$ Freeze Dry System (Labconco Corp., Kansas City, MO) and stored in airtight containers at $-20^{\circ} \mathrm{C}$ (Mukherjee et al., 2019).

\subsection{Preparation of Enzymatic Hydrolysate of Casein}

The casein curd was prepared using $0.1 \mathrm{~N} \mathrm{HCl}$ with skimmed milk that was allowed to stand at $22^{\circ} \mathrm{C}$ for $30 \mathrm{~min}$. The curd was strained and re-dispersed by vortexing in $0.1 \mathrm{~N} \mathrm{NaOH}$ (final $\mathrm{pH} 7.8$ ) to obtain a $1 \%(\mathrm{w} / \mathrm{v}$ ) dispersion. Chymotrypsin (Sigma Aldrich, St. Louis, MD) was used to digest freshly prepared acid casein (Haque et al., 1993) at a chymotrypsin to casein ratio of 1:60. The digestion mixture was adjusted to $\mathrm{pH} 7.8$ using $100 \mathrm{mM}$ Tris $\mathrm{HCl}$, that contained $10 \mathrm{mM} \mathrm{CaCl}_{2}$ at $37^{\circ} \mathrm{C}$ for $1 \mathrm{~h}$. Digestion was terminated using $0.1 \mathrm{~N} \mathrm{HCl}$ to adjust the $\mathrm{pH}$ to 2.0. After digestion, the mixture was centrifuged, and the pellet was freeze dried and stored in an airtight container (7-1/2" x 5-1/4" x 8" h, SKU \# 10062481 model, Oxo Good Grip, Chambersburg, PA 17201) at $-20^{\circ} \mathrm{C}$.

\subsection{Emulsion Preparation}

WPI $(1 \%$, w/v), tween $20(20 \%$, w/w of WPI), and CU $(0.22 \%$, w/v $)$ were gently stirred into the continuous phase for $3 \mathrm{~h}$ at $22^{\circ} \mathrm{C}$, which consisted of $200 \mathrm{mM}$ potassium phosphate buffer ( $\mathrm{pH}$ 8.0). The reaction was stopped immediately by adding $10 \mathrm{~N} \mathrm{HCl}$ and lowering the $\mathrm{pH}$ to 5.6 . The dispersed phase $(1 \%, \mathrm{v} / \mathrm{v}$ of the continuous phase) was then introduced. A coarse emulsion was prepared by blending the incubated mixture for 3 min on low speed, followed immediately by a single pass $(5-10 \mathrm{sec})$ of UHPH through a benchtop ultra-high-pressure homogenizer (FPG 11300, Stansted Fluid Power Ltd., Essex, U.K.) at 140 or 210 MPa at $22^{\circ} \mathrm{C}$ to generate the CU-cargo loaded nano vesicular vehicle (NVV) (Calligaris et al., 2016).

\subsection{Particle Size Measurement}

Dispersed phase volume-surface average diameter $\left(\mathrm{d}_{\mathrm{vs}}\right)$ was measured using a Microtrac S3500 Particle Size Analyzer (Nikkiso, Tokyo, Japan) based on the expression: 


$$
\sum V_{i} / \sum\left(\frac{V_{i}}{d_{i}}\right)
$$

where $\mathrm{V}_{\mathrm{i}}$ is denoted as volume of globules in a size class of mean diameter $\mathrm{d}_{\mathrm{i}}$.

\subsection{Zeta-potential Measurement}

The zeta-potential of the emulsions was determined with a Zetasizer Nano ZS-90 (Malvern Instruments, Worcestershire, U.K.). Emulsions were diluted 1/1,000 (w/w) in $10 \mathrm{mM}$ potassium phosphate buffer (pH 5.6) to avoid multiple scattering effects. The zeta-potential of the sample was calculated using the Smoluchowski model that is based on particle electrophoretic mobility.

\subsection{Contact angle and Surface Energy Measurements}

Contact angle of the emulsion was determined using a Goniometer model 260 (Ramé-Hart instrument Co., Succasunna, NJ), with DROPimage Advanced software for image acquisition and analysis. The surface energy was calculated using the Surface Energy Tool according to Young's equation.

\subsection{Antioxidant Activity (AA) and Antioxidant Persistence (AP)}

The AA and AP of the NVV were determined following a method that was described by Haque et al. (2013). Assays were conducted in clear bottom 96 well plates and each reaction mixture consisted of $50 \mu \mathrm{L}$ of each component including the emulsion sample (subjected to specific treatments), $12.5 \mathrm{mM} \mathrm{ABAP}, 10 \mathrm{mM}$ luminol and oxygen-saturated potassium phosphate buffer ( $\mathrm{pH}$ 5.6). Trolox (20 mM) was used as a positive control. Peroxyl and alkoxyl radicals that were generated in vitro by pyrolysis of ABAP and unquenched radicals were detected by luminol-induced chemiluminescence (relative light unit, RLU) and used to determine the AA of the NVV. AA was expressed by its chemiluminescence value that corresponded to the chemiluminescence maxima of the blank (the buffer on its own), which indicated maximum free radical production. Thus, AA for NVV depicted its efficacy at scavenging radicals at their highest concentration in an in vitro model system. When chemiluminescence of the blank ceased after $60 \mathrm{~min}$, depicting an apparent reduction in radical generation, a second luminescence curve was initiated. This was done by re-induction of pyrolysis of an equal volume and concentration of ABAP that was induced in the same reaction chambers (wells). Residual antioxidant activity of NVV was a reflection of its AP, which was calculated using the same method that was used to calculate AA. Detection of unquenched radicals was based on the chemiluminescence of luminal that was measured at 1.50 min intervals using a FlexStation 3 Microplate Reader (Molecular Devices, CA), that was assembled with SoftMax ${ }^{\circledR}$ Pro Microplate Data Acquisition \& Analysis Software. Greater AA and AP are indicated by lesser RLUs.

\subsection{Morphology of Stabilized Nano-emulsions}

The nano-emulsions $(2.0 \mu \mathrm{L})$ were diluted 50 times using $200 \mathrm{mM}$ potassium phosphate buffer $(\mathrm{pH} 8.0)$ buffer and smeared to the carbon-coated grids. Excess buffer solution was blotted with filter paper. The grids were dried under ambient condition and imaged without staining. Imaging was performed using a JEOL 1230 Transmission electron Microscope (TEM) operating at $120 \mathrm{kV}$ (Tokyo, Japan).

\subsection{Statistical Analysis}

The experiments were designed in $2 \times 4$ factorial arrangement with 3 replications with pressure (140 MPa and $210 \mathrm{MPa}$ ) and treatment (WPI, WPICU, WPICH, WPICUCH) and a split plot factor of storage time within the factorial design. All data analysis was performed using SAS 9.3 (SAS institute Inc., Cary, NC USA). Means were separated using Tukey's Honestly Significant Difference Test $(\mathrm{P}<0.05)$ for main and interaction effects to evaluate the impact of treatment and pressure over storage time on the emulsion stability $(n=3)$, antioxidant activity (AA, $n=5)$, and antioxidant persistence $(\mathrm{AP}, \mathrm{n}=5)$ of the emulsion systems.

\section{Results and Discussion}

\subsection{Mean Surface Globular Diameter $\left(d_{v s}\right)$}

When averaged over pressure and storage time, the WPICU treatment had a greater $(\mathrm{P}<0.05)$ mean globular diameter $\left(\mathrm{d}_{\mathrm{vs}}\right)$ than all other treatments. The addition of $\mathrm{CH}$ to both WPI and WPICU caused a decrease in $\mathrm{d}_{\mathrm{vs}}$ $(\mathrm{P}<0.05)$ (Table 1). This indicates that the addition of CU decreased the emulsion stability of WPI, while the addition of $\mathrm{CH}$ increased emulsion stability, both with and without $\mathrm{CU}$. Increasing protein concentration in nanoemulsion decrease of globule diameter was supported by the previous studies ( $\mathrm{Li}$ et al. 2014). When averaged over treatment and storage time, there was no difference in $\mathrm{d}_{\mathrm{vs}}$ between the 140 and $210 \mathrm{MPa}$ pressure treatments. For storage time, averaged over treatment and pressure, no difference existed in $d_{v s}$ from 0 to $4 \mathrm{~d}, d_{v s}$ 
increased $(\mathrm{P}<0.05)$ from 4 to $8 \mathrm{~d}$ of storage and then increased again between 12 and $16 \mathrm{~d}$ of storage. This indicates that emulsion stability generally decreased over time. When the treatment $\times$ pressure interaction was averaged over time, the WPICH treatments at 140 and $210 \mathrm{MPa}$ and WPI treatment at $140 \mathrm{MPa}$ had a smaller $\mathrm{d}_{\mathrm{vs}}$ $(\mathrm{P}<0.05)$ than all other treatment combinations. Addition of $\mathrm{CH}$ increased $(\mathrm{P}<0.05)$ the stability $\left(\right.$ decreased $\left.\mathrm{d}_{\mathrm{vs}}\right)$ of the WPICU treatment at $140 \mathrm{MPa}$ but did not decrease $\mathrm{d}_{\mathrm{vs}}(\mathrm{P}>0.05)$ at $210 \mathrm{MPa}$. When the pressure $\times$ time interaction was averaged over treatment, the $\mathrm{d}_{\mathrm{vs}}$ increased $(\mathrm{P}<0.05)$ more quickly over time at $140 \mathrm{MPa}$ then at $210 \mathrm{MPa}$. When treatment $\times$ time was averaged over pressure, the WPICU treatment had increased from its initial $d_{v s}$ by 8 days but the $d_{v s}$ of the WPICUCH treatment did not increase to values similar to WPICU until 20 days of storage. The mean separation for the treatment $\times$ pressure $\times$ time interaction indicated that the most stable emulsion was the WPI primary emulsion treatment with the addition of casein hydrolysate over 28 days of storage. In addition, the $210 \mathrm{MPa}$ treatments of WPICH were generally more stable than those at $140 \mathrm{MPa}$ over time with the exception of the primary WPI emulsion. Addition of CU to WPI led to a greater $\mathrm{d}_{\mathrm{vs}}(\mathrm{P}<0.05)$ after 8 days of storage at $140 \mathrm{MPa}$. Addition of $\mathrm{CH}$ and/or pressure of $210 \mathrm{MPa}$ had lower $\mathrm{d}_{\mathrm{vs}}$ than WPICU at $140 \mathrm{MPa}$ by 8 days through the $28 \mathrm{~d}$ storage time. Use of $\mathrm{CH}$ improved the storage stability of the nanoemulsion, which may have been due to concentration and viscosity effects. Results are consistent with researchers who reported that casein hydrolysate was an effective emulsifier in cheese (Adjonu et al., 2014; Kwak et al., 2002) due to its ability to reduce the particle size in micro and nanoemulsions (Su and Zhong, 2016). Size reduction of the particles previously imparted stability in WPI based emulsions that carried the bioactive component, naringin (Hu et al. 2020). The mean NVV monomodal distribution of the emulsion was $17 \%$ smaller at $210 \mathrm{MPa}$ when compared to $140 \mathrm{MPa}$. Addition of $\mathrm{CH}$ also increased the stability with UHPH pressure as reflected by $63 \%$ smaller $\mathrm{d}_{\mathrm{vs}}$ at $210 \mathrm{MPa}$ as compared to $140 \mathrm{MPa}$.

Table 1. Mean globular diameter (dvs, $\mu \mathrm{m})$ of the WPI (1\%), tween $20(20 \%$ of WPI), peanut oil $(\Phi=0.05)$, and/or casein hydrolysate (2\% of WPI) formulated nano-vesicular vehicles and curcumin loaded vesicular vehicles that were subjected to 140 and $210 \mathrm{MPa}$ of homogenization (single pass) over 28 days of storage

\begin{tabular}{lllllllllll}
\hline Treatment & Pressure (MPa) & Day 0 & Day 2 & Day 4 & Day 8 & Day 12 & Day 16 & Day 20 & Day 24 & Day 28 \\
\hline WPI & 140 & $113^{\mathrm{AB}}$ & $87^{\mathrm{B}}$ & $86^{\mathrm{B}}$ & $103^{\mathrm{BC}}$ & $109^{\mathrm{BC}}$ & $94^{\mathrm{B}}$ & $91^{\mathrm{C}}$ & $94^{\mathrm{C}}$ & $83^{\mathrm{C}}$ \\
WPI & 210 & $151^{\mathrm{Ab}}$ & $175^{\mathrm{Aab}}$ & $114^{\mathrm{ABb}}$ & $142^{\mathrm{Bb}}$ & $107^{\mathrm{BCb}}$ & $181^{\mathrm{ABab}}$ & $181^{\mathrm{Bab}}$ & $181^{\mathrm{Bab}}$ & $205^{\mathrm{ABa}}$ \\
WPICU & 140 & $80^{\mathrm{Bd}}$ & $68^{\mathrm{Bd}}$ & $154^{\mathrm{Ac}}$ & $234^{\mathrm{Aab}}$ & $264^{\mathrm{Aa}}$ & $218^{\mathrm{Aab}}$ & $251^{\mathrm{Aab}}$ & $251^{\mathrm{Aab}}$ & $213^{\mathrm{Ab}}$ \\
WPICU & 210 & $86^{\mathrm{Bb}}$ & $98^{\mathrm{Bb}}$ & $77^{\mathrm{Bb}}$ & $100^{\mathrm{BCb}}$ & $112^{\mathrm{BCb}}$ & $131^{\mathrm{Bab}}$ & $135^{\mathrm{BCab}}$ & $177^{\mathrm{Ba}}$ & $178^{\mathrm{ABa}}$ \\
WPICH & 140 & $101^{\mathrm{ABab}}$ & $78^{\mathrm{Bb}}$ & $81^{\mathrm{Bb}}$ & $95^{\mathrm{Cb}}$ & $150^{\mathrm{Ba}}$ & $101^{\mathrm{Bab}}$ & $105^{\mathrm{Cab}}$ & $108^{\mathrm{Cab}}$ & $106^{\mathrm{Cab}}$ \\
WPICH & 210 & $73^{\mathrm{Bb}}$ & $77^{\mathrm{Bb}}$ & $135^{\mathrm{ABa}}$ & $89^{\mathrm{Cab}}$ & $91^{\mathrm{Cab}}$ & $95^{\mathrm{Bab}}$ & $82^{\mathrm{Cb}}$ & $88^{\mathrm{Cab}}$ & $73^{\mathrm{Cb}}$ \\
WPICUCH & 140 & $88^{\mathrm{Bb}}$ & $96^{\mathrm{Bb}}$ & $96^{\mathrm{Bb}}$ & $122^{\mathrm{BCb}}$ & $108^{\mathrm{BCb}}$ & $189^{\mathrm{Aa}}$ & $165^{\mathrm{Bab}}$ & $166^{\mathrm{Bab}}$ & $169^{\mathrm{ABab}}$ \\
WPICUCH & 210 & $92^{\mathrm{Bc}}$ & $130^{\mathrm{ABbc}}$ & $93^{\mathrm{BCbc}}$ & $115^{\mathrm{BCbc}}$ & $152^{\mathrm{Bb}}$ & $203^{\mathrm{Aa}}$ & $162^{\mathrm{Bab}}$ & $166^{\mathrm{Bab}}$ & $162^{\mathrm{Bab}}$ \\
\hline
\end{tabular}

WPI: whey protein isolate, $\mathrm{CU}$ : curcumin, $\mathrm{CH}$ : casein hydrolysate.

Significant differences within each row (lowercase) or each column (uppercase) are indicated by different letters $(\mathrm{P}<0.05)$.

\subsection{Zeta Potential (५)}

The zeta potential ( $\zeta$-potential), also known is the electrokinetic potential, is a measurement of the electrical charge of particles that are suspended in a liquid and is often used to describe double-layer properties of a colloidal dispersion. Typically, the higher the absolute values of the zeta-potential, the more stable the colloid. The absolute value of zeta potential and colloidal stability was also supported by previous study on extracellular vesicles which is similar to our colloidal NVV system (Medikessa et al., 2020). Zeta potentials less negative than $-15 \mathrm{mV}$ typically represent the initial stage of particle agglomeration. When the zeta-potential equals zero, the colloid will precipitate into a solid (Hunter, 2013). When averaged over pressure and storage time, WPI had the least absolute zeta potential $(\mathrm{P}<0.05)$ followed by WPICU, WPICUCH, and WPICH (Table 2). The emulsions with $\mathrm{CH}$ had greater absolute zeta potential $(\mathrm{P}<0.05)$ than the WPICU and WPI treatments, regardless of whether $\mathrm{CU}$ was present in the emulsion or not. These treatments had zetas of approximately $-50 \mathrm{mV}$, which are reasonably stable (-40 to $-60 \mathrm{mV}$ ) (Riddick, 1968). This is in comparison to the emulsions without $\mathrm{CH}$, which were moderately stable $(-30$ to $-40 \mathrm{mV})$. When pressure was averaged over treatment and time, the $210 \mathrm{MPa}$ had a greater absolute zeta potential $(\mathrm{P}<0.05)$ than $140 \mathrm{MPa}$. When treatment $\times$ pressure was averaged over storage time, the addition of $\mathrm{CH}$ to WPI and WPICU slightly increased $(\mathrm{P}<0.05)$ absolute zeta potential at $140 \mathrm{MPa}$. However, at $210 \mathrm{MPa}$, the addition of $\mathrm{CH}$ to WPI and WPICU greatly increased $(\mathrm{P}<0.05)$ absolute zeta potential by approximately 20 units in comparison to a 5 unit approximate increase at $140 \mathrm{MPa}$. When means were separated for the treatment $\times$ pressure $\times$ time interaction, the WPICH treatments at $210 \mathrm{MPa}$ had greater absolute zeta potentials $(\mathrm{P}<0.05)$ than all other treatments, with the exception of WPICUCH at 210 MPA at 2-4 days of storage. The absolute zeta potentials of WPICH and WPICUCH treatments at $210 \mathrm{MPa}$ were between 57 and 60 
$\mathrm{mV}$, which ranged right on the border between an emulsion with very good stability and reasonable stability. The results indicate that the pressure of $210 \mathrm{MPa}$ and the use of $\mathrm{CH}$ might promote limited hydrolysis of WPI. A similar process has been utilized to generate peptides of smaller size with few secondary and tertiary protein conformations and a partially revealed hydrophobic core that enhances emulsification (Gauthier \& Pouliot, 2003; Tirok et al., 2001). In general, a higher rate of diffusion has been exhibited by hydrolysates such as $\mathrm{CH}$ at the $\mathrm{O} / \mathrm{W}$ interface, which can spread a larger area of the interface than the uncleaved or native protein and therefore has a greater ability to emulsify and stabilize the oil phase (Davis et al., 2005; O'Regan \& Mulvihill, 2010). The NVV (WPICH) prepared with $210 \mathrm{MPa}$ UHPH had the highest absolute $\zeta$ value $(60.1 \mathrm{mV})$ compared to other treatments after $28 \mathrm{~d}$ of storage. The next highest absolute $\zeta$ value $(57.4 \mathrm{mV})$ was WPICUCH that was prepared with $210 \mathrm{MPa}$ UHPH. This is likely due to the increased surface charge that $\mathrm{CH}$ is known to contribute to the stability of nanoparticles from the co-localization of hydroxyl, amine, and carboxyl groups on the NVV+CU surface (Basumallick et al., 2016).

Table 2. Mean absolute zeta potential $(\zeta, \mathrm{mV})$ of the WPI $(1 \%)$, tween $20(20 \%$ of WPI), peanut oil $(\Phi=0.05)$, and/or casein hydrolysate (2\% of WPI) formulated nano-vesicular vehicles and curcumin loaded vesicular vehicles that were subjected to 140 and $210 \mathrm{MPa}$ of homogenization (single pass) over 28 days of storage

\begin{tabular}{lllllllllll}
\hline Treatment & Pressure (MPa) & Day 0 & Day 2 & Day 4 & Day 8 & Day 12 & Day 16 & Day 20 & Day 24 & Day 28 \\
\hline WPI & 140 & $33.9^{\mathrm{Dd}}$ & $40.9^{\mathrm{Bab}}$ & $34.9^{\mathrm{Cd}}$ & $42.0^{\mathrm{Ca}}$ & $37.1^{\mathrm{Fc}}$ & $39.5^{\mathrm{Eb}}$ & $38.6^{\mathrm{Ebc}}$ & $40.1^{\mathrm{Db}}$ & $41.3^{\mathrm{Dab}}$ \\
WPI & 210 & $30.2^{\mathrm{Ed}}$ & $33.2^{\mathrm{Ec}}$ & $28.6^{\mathrm{Ed}}$ & $37.5^{\mathrm{Db}}$ & $37.6^{\mathrm{Fb}}$ & $39.4^{\mathrm{Ea}}$ & $38.7^{\mathrm{Eab}}$ & $37.7^{\mathrm{Eb}}$ & $37.5^{\mathrm{Eb}}$ \\
WPICU & 140 & $30.5^{\mathrm{Ee}}$ & $34.7^{\mathrm{Dd}}$ & $32.0^{\mathrm{De}}$ & $36.4^{\mathrm{Dc}}$ & $52.8^{\mathrm{Ca}}$ & $42.0^{\mathrm{Db}}$ & $43.6^{\mathrm{Cb}}$ & $42.5^{\mathrm{Cb}}$ & $42.1^{\mathrm{CDb}}$ \\
WPICU & 210 & $29.4^{\mathrm{Ef}}$ & $38.1^{\mathrm{Cd}}$ & $32.3^{\mathrm{De}}$ & $33.6^{\mathrm{Ee}}$ & $44.7^{\mathrm{Da}}$ & $44.3^{\mathrm{Cab}}$ & $42.7^{\mathrm{Cb}}$ & $40.9^{\mathrm{CDc}}$ & $40.3^{\mathrm{Dc}}$ \\
WPICH & 140 & $42.4^{\mathrm{Cb}}$ & $42.3^{\mathrm{Bb}}$ & $42.7^{\mathrm{Bab}}$ & $42.6^{\mathrm{Cb}}$ & $44.3^{\mathrm{Da}}$ & $43.0^{\mathrm{CDab}}$ & $43.3^{\mathrm{Cab}}$ & $42.5^{\mathrm{Cb}}$ & $43.7^{\mathrm{Cab}}$ \\
WPICH & 210 & $60.1^{\mathrm{A}}$ & $59.3^{\mathrm{A}}$ & $59.7^{\mathrm{A}}$ & $59.7^{\mathrm{A}}$ & $59.8^{\mathrm{A}}$ & $59.8^{\mathrm{A}}$ & $60.5^{\mathrm{A}}$ & $60.4^{\mathrm{A}}$ & $60.1^{\mathrm{A}}$ \\
WPICUCH & 140 & $41.3^{\mathrm{C}}$ & $41.6^{\mathrm{B}}$ & $41.3^{\mathrm{B}}$ & $41.0^{\mathrm{C}}$ & $41.0^{\mathrm{E}}$ & $41.0^{\mathrm{DE}}$ & $41.0^{\mathrm{D}}$ & $41.0^{\mathrm{CD}}$ & $41.3^{\mathrm{D}}$ \\
WPICUCH & 210 & $58.2^{\mathrm{B}}$ & $58.0^{\mathrm{A}}$ & $58.2^{\mathrm{A}}$ & $57.2^{\mathrm{B}}$ & $57.1^{\mathrm{B}}$ & $57.1^{\mathrm{B}}$ & $57.1^{\mathrm{B}}$ & $57.1^{\mathrm{B}}$ & $57.5^{\mathrm{B}}$ \\
\hline
\end{tabular}

WPI: whey protein isolate, $\mathrm{CU}$ : curcumin, $\mathrm{CH}$ : casein hydrolysate.

Significant differences within each row (lowercase) or each column (uppercase) are indicated by different letters $(\mathrm{P}<0.05)$.

\subsection{Contact Angle and Surface Energy}

Contact angle (CA) is the measurement of wettability of the oil in water or water in oil emulsions (Sjöblom et al., 1992). A contact angle of $\theta=90^{\circ}$ for an oil $/$ water/solid emulsion means that the dispersed particles are optimally stabilized in an emulsion system. If $\theta$ is less than $90^{\circ}$, an oil soluble surfactant must be added to stabilize the emulsion (Sjöblom et al., 1992). Contact angle values were $35^{\circ}$ to $65^{\circ}$ in the current study since the hydrophilic protein, WPI, is included in the emulsion (Table 3). These values are indicative of stabilized emulsions with greater values indicating greater stability (Destribats et al., 2014). When averaged over storage time and pressure, WPICH had the greatest CA $(\mathrm{P}<0.05)$, followed by WPICUCH, WPI, and then WPICU, with less than a 2-unit difference between WPICH and WPICUCH (Table 3). However, the WPI and WPICU treatments that did not contain $\mathrm{CH}$ had $\mathrm{CA}$ values that were 10 units less than treatments with $\mathrm{CH}(\mathrm{P}<0.05)$. When averaged over treatment and storage time, the $210 \mathrm{MPa}$ pressure increased $(\mathrm{P}<0.05)$ the $\mathrm{CA}$ by almost 8 units (Table 3$)$ and increased $(\mathrm{P}<0.05)$ the surface energy by 0.3 units (Table 4$)$, indicating that the pressure increased the electrostatic repulsion and hence emulsion stability (McClements, 2005). When treatment and pressure combinations were averaged over storage time, the WPICU treatments at $140 \mathrm{MPa}$ and $210 \mathrm{MPa}$ had a smaller $\mathrm{CA}(\mathrm{P}<0.05)$ than all other treatments, indicating that the addition of $\mathrm{CU}$ made the emulsion less stable. In addition, WPICH at $210 \mathrm{MPa}$ had the greatest CA, signifying that it was the most stable emulsion, followed by WPICUCH at $210 \mathrm{MPa}$ (Table 3). When means were separated over the combination of treatment, pressure, and storage time, the WPICH treatments at $210 \mathrm{MPa}$ had a greater CA than the WPICUCH treatment at $210 \mathrm{MPa}$ at 0 , $8,12,16,20$, and 28 days of storage. This indicates that the emulsion without $\mathrm{CU}$ had a greater electrostatic repulsion, signifying greater stability. However, the small decrease in stability due to CU addition is much less than the increase in CA due to the combination effects of $\mathrm{CH}$ and a pressure of $210 \mathrm{MPa}$ that stabilized the emulsion. In contrast to the CA results, the WPICUCH treatment at 210 MPA had a greater SE $(\mathrm{P}<0.05)$ than all other treatments at day 28 (Table 4), indicating greater electrostatic repulsion at the surface than in any other treatments. The aggregation pattern of WPI without $\mathrm{CH}$ and $\mathrm{CU}$ supported the assumption that UHPH increased the temperature of the emulsion, which created a high cavitation force that exceeded the Laplace pressure (the differential pressure between the inside and outside of a curved surface), therefore reducing the wettability of WPI (Paunov et al., 2007). The addition of $\mathrm{CH}$ as an amphiphile may create a wedging affect that reduces contact angle and enhances the stability of the emulsion system. 
Table 3. Mean contact angle $\left(\theta,{ }^{\circ}\right)$ of the WPI $(1 \%)$, tween $20(20 \%$ of WPI), peanut oil $(\Phi=0.05)$, and/or casein hydrolysate ( $2 \%$ of WPI) formulated nano-vesicular vehicles and curcumin loaded vesicular vehicles that were subjected to 140 and $210 \mathrm{MPa}$ of homogenization (single pass) over 28 days of storage

\begin{tabular}{lllllllllll}
\hline Treatment & Pressure (MPa) & Day 0 & Day 2 & Day 4 & Day 8 & Day 12 & Day 16 & Day 20 & Day 24 & Day 28 \\
\hline WPI & 140 & $36.7^{\mathrm{Ge}}$ & $39.2^{\mathrm{Fc}}$ & $46.2^{\mathrm{Ca}}$ & $40.2^{\mathrm{Eb}}$ & $39.9^{\mathrm{Eb}}$ & $39.6^{\mathrm{Ebc}}$ & $39.2^{\mathrm{Dcd}}$ & $38.5^{\mathrm{Dcd}}$ & $38.5^{\mathrm{Ed}}$ \\
WPI & 210 & $43.8^{\mathrm{Cb}}$ & $46.3^{\mathrm{Ca}}$ & $42.7^{\mathrm{Dc}}$ & $37.1^{\mathrm{Hde}}$ & $37.6^{\mathrm{Gd}}$ & $37.1^{\mathrm{Gde}}$ & $36.8^{\mathrm{Fe}}$ & $36.8^{\mathrm{Ee}}$ & $36.7^{\mathrm{Fe}}$ \\
WPICU & 140 & $38.0^{\mathrm{Fb}}$ & $35.5^{\mathrm{Gd}}$ & $37.0^{\mathrm{Fc}}$ & $39.3^{\mathrm{Fa}}$ & $39.2^{\mathrm{Fa}}$ & $38.4^{\mathrm{Fb}}$ & $38.2^{\mathrm{Eb}}$ & $38.3^{\mathrm{Db}}$ & $38.3^{\mathrm{Eb}}$ \\
WPICU & 210 & $36.5^{\mathrm{Gc}}$ & $36.1^{\mathrm{Gc}}$ & $41.0^{\mathrm{Ea}}$ & $37.9^{\mathrm{Gb}}$ & $37.6^{\mathrm{Gb}}$ & $36.6^{\mathrm{Gc}}$ & $36.0^{\mathrm{Gc}}$ & $35.9^{\mathrm{Fc}}$ & $36.0^{\mathrm{Fc}}$ \\
WPICH & 140 & $41.3^{\mathrm{Ec}}$ & $41.6^{\mathrm{Ec}}$ & $41.3^{\mathrm{Ec}}$ & $41.0^{\mathrm{Dc}}$ & $41.0^{\mathrm{Dc}}$ & $41.0^{\mathrm{Dc}}$ & $41.0^{\mathrm{Cc}}$ & $42.5^{\mathrm{Cb}}$ & $48.5^{\mathrm{Ca}}$ \\
WPICH & 210 & $60.1^{\mathrm{Abc}}$ & $59.3^{\mathrm{Ac}}$ & $59.7^{\mathrm{Ac}}$ & $59.7^{\mathrm{Ac}}$ & $59.8^{\mathrm{Abc}}$ & $59.8^{\mathrm{Abc}}$ & $60.5^{\mathrm{Ab}}$ & $60.4^{\mathrm{Abc}}$ & $62.6^{\mathrm{Aa}}$ \\
WPICUCH & 140 & $42.3^{\mathrm{Dc}}$ & $42.7^{\mathrm{Dbc}}$ & $42.6^{\mathrm{Dc}}$ & $44.3^{\mathrm{Ca}}$ & $43.0^{\mathrm{Cbc}}$ & $43.3^{\mathrm{Cb}}$ & $40.4^{\mathrm{Cd}}$ & $43.4^{\mathrm{Bb}}$ & $44.1^{\mathrm{Dab}}$ \\
WPICUCH & 210 & $58.2^{\mathrm{Bb}}$ & $58.0^{\mathrm{Bb}}$ & $58.2^{\mathrm{Bb}}$ & $57.2^{\mathrm{Bc}}$ & $57.1^{\mathrm{Bc}}$ & $57.1^{\mathrm{Bc}}$ & $57.1^{\mathrm{Bc}}$ & $60.4^{\mathrm{Aa}}$ & $57.1^{\mathrm{Bc}}$ \\
\hline
\end{tabular}

WPI: whey protein isolate, $\mathrm{CU}$ : curcumin, $\mathrm{CH}$ : casein hydrolysate.

Significant differences within each row (lowercase) or each column (uppercase) are indicated by different letters $(\mathrm{P}<0.05)$.

Table 4. Mean surface energy $(\mathrm{mJ} / \mathrm{m} 2)$ of the WPI $(1 \%)$, tween $20(20 \%$ of WPI), peanut oil $(\Phi=0.05)$, and/or casein hydrolysate ( $2 \%$ of WPI) formulated nano-vesicular vehicles and curcumin loaded vesicular vehicles that were subjected to 140 and $210 \mathrm{MPa}$ of homogenization (single pass) over 28 days of storage

\begin{tabular}{lllllllllll}
\hline Treatment & Pressure (MPa) & Day 0 & Day 2 & Day 4 & Day 8 & Day 12 & Day 16 & Day 20 & Day 24 & Day 28 \\
\hline WPI & 140 & $60.0^{\mathrm{Bab}}$ & $60.3^{\mathrm{Abab}}$ & $57.5^{\mathrm{Ac}}$ & $58.0^{\mathrm{Bbc}}$ & $59.3^{\mathrm{Bb}}$ & $60.4^{\mathrm{Aab}}$ & $61.3^{\mathrm{BCa}}$ & $61.4^{\mathrm{BCa}}$ & $61.3^{\mathrm{BCa}}$ \\
WPI & 210 & $59.5^{\mathrm{Bb}}$ & $60.2^{\mathrm{Abab}}$ & $57.7^{\mathrm{Ac}}$ & $58.1^{\mathrm{Bbc}}$ & $59.7^{\mathrm{ABab}}$ & $61.3^{\mathrm{Aa}}$ & $58.5^{\mathrm{Dbc}}$ & $58.5^{\mathrm{Dbc}}$ & $58.5^{\mathrm{Dbc}}$ \\
WPICU & 140 & $59.9^{\mathrm{Bab}}$ & $57.2^{\mathrm{Cb}}$ & $57.9^{\mathrm{Ab}}$ & $58.4^{\mathrm{Bb}}$ & $59.9^{\mathrm{ABab}}$ & $58.5^{\mathrm{Bb}}$ & $60.3^{\mathrm{Ca}}$ & $60.3^{\mathrm{Ca}}$ & $60.3^{\mathrm{Ca}}$ \\
WPICU & 210 & $60.1^{\mathrm{Ba}}$ & $57.5^{\mathrm{Cb}}$ & $57.9^{\mathrm{Ab}}$ & $58.4^{\mathrm{Bb}}$ & $60.0^{\mathrm{ABab}}$ & $60.3^{\mathrm{Aa}}$ & $60.4^{\mathrm{Ca}}$ & $60.4^{\mathrm{Ca}}$ & $60.4^{\mathrm{Ca}}$ \\
WPICH & 140 & $59.0^{\mathrm{Bb}}$ & $60.8^{\mathrm{Aba}}$ & $58.8^{\mathrm{Ab}}$ & $60.4^{\mathrm{Aab}}$ & $59.2^{\mathrm{Bb}}$ & $60.5^{\mathrm{Aab}}$ & $60.9^{\mathrm{BCa}}$ & $60.6^{\mathrm{BCab}}$ & $60.6^{\mathrm{BCab}}$ \\
WPICH & 210 & $59.2^{\mathrm{Bb}}$ & $61.7^{\mathrm{Aa}}$ & $58.6^{\mathrm{Ab}}$ & $56.9^{\mathrm{Bc}}$ & $61.3^{\mathrm{Aa}}$ & $60.6^{\mathrm{Aab}}$ & $61.2^{\mathrm{BCa}}$ & $61.2^{\mathrm{BCa}}$ & $62.1^{\mathrm{Ba}}$ \\
WPICUCH & 140 & $60.0^{\mathrm{Bb}}$ & $59.2^{\mathrm{Bbc}}$ & $53.4^{\mathrm{Bd}}$ & $58.0^{\mathrm{Bc}}$ & $60.0^{\mathrm{Abb}}$ & $60.6^{\mathrm{Aab}}$ & $62.1^{\mathrm{Ba}}$ & $62.1^{\mathrm{Ba}}$ & $58.7^{\mathrm{Dbc}}$ \\
WPICUCH & 210 & $62.0^{\mathrm{Ab}}$ & $59.7^{\mathrm{Bc}}$ & $54.1^{\mathrm{Be}}$ & $58.2^{\mathrm{Bd}}$ & $60.3^{\mathrm{Abc}}$ & $60.4^{\mathrm{Ac}}$ & $64.3^{\mathrm{Aa}}$ & $64.4^{\mathrm{Aa}}$ & $65.2^{\mathrm{Aa}}$ \\
\hline
\end{tabular}

WPI: whey protein isolate, $\mathrm{CU}$ : curcumin, $\mathrm{CH}$ : casein hydrolysate.

Significant differences within each row (lowercase) or each column (uppercase) are indicated by different letters $(\mathrm{P}<0.05)$.

\subsection{Antioxidant Activity and Persistence}

When averaged over storage time and pressure, the WPICU treatment had greater antioxidant activity $(\mathrm{P}<0.05)$ than all other treatments, followed by WPICUCH, which had greater AA and AP $(\mathrm{P}<0.05)$ than the treatments without $\mathrm{CU}$ (Tables 5 and 6). Adding $\mathrm{CH}$ to the treatment with $\mathrm{CU}$ slightly decreased the AA and AP (Tables 5 and 6). In contrast, adding CH to WPI, slightly decreased AA, but slightly increased AP. This is likely due to a dilution effect when $\mathrm{CH}$ is included in the formulation since $\mathrm{CU}$ is a strong antioxidant due to its high radical scavenging ability. Casein - pectin/protein nano complexes were shown to exhibit higher antioxidant activity carrying curcumin (Hua et al., 2021). On average, the AA and AP of WPICUCH and WPICU were less than that of Trolox $(20 \mathrm{mM})$, indicating greater AA and AP. The AA and AP values for WPICH and WPI treatments were much greater than Trolox, indicating less AA and AP. Since the differences were so vast between treatments with and without $\mathrm{CU}$ added, results were analyzed separately for the data with $\mathrm{CU}$ and the data without curcumin. For treatments with $\mathrm{CU}$, the maximum AA was at $\mathrm{d} 0$, with an RLU value of 3.1 when averaged over storage times (Table 5). The value at $\mathrm{d} 0$ was less than all other treatments $(\mathrm{P}<0.05)$. As storage time increased to day 8 , AA increased, signifying a decreased antioxidant activity. No differences existed in AA $(\mathrm{P}>0.05)$ between 8 and $24 \mathrm{~d}$ of storage with values of approximately 10 at $140 \mathrm{MPa}$ and 12 at $210 \mathrm{MPa}$.

Table 5. Mean antioxidant activity (relative light unit, RLU) of the WPI (1\%), tween 20 (20\% of WPI), peanut oil $(\Phi=0.05)$, and/or casein hydrolysate ( $2 \%$ of WPI) formulated nano-vesicular vehicles and curcumin loaded vesicular vehicles that were subjected to 140 and $210 \mathrm{MPa}$ of homogenization (single pass) over 28 days of storage

\begin{tabular}{|c|c|c|c|c|c|c|c|c|c|c|c|}
\hline Treatment & & Pressure (MPa) & Day 0 & Day 2 & Day 4 & Day 8 & Day 12 & Day 16 & Day 20 & Day 24 & Day 28 \\
\hline \multirow[t]{4}{*}{ Without CU } & WPI & 140 & $64.5^{\mathrm{Bb}}$ & $72.7^{\mathrm{ABb}}$ & $97.0^{\mathrm{Aa}}$ & $71.8^{\mathrm{Ab}}$ & $72.1^{\mathrm{Ab}}$ & $72.9^{\mathrm{Ab}}$ & $72.8^{\mathrm{Ab}}$ & $72.8^{\mathrm{Ab}}$ & $72.8^{\mathrm{Ab}}$ \\
\hline & WPI & 210 & $64.8^{\mathrm{Bbc}}$ & $67.7^{\mathrm{Bbc}}$ & $90.3^{\mathrm{Aa}}$ & $71.6^{\mathrm{Ab}}$ & $59.3^{\mathrm{Bc}}$ & $63.1^{\mathrm{Abc}}$ & $62.5^{\mathrm{Abc}}$ & $62.9^{\mathrm{Abc}}$ & $62.5^{\mathrm{Abc}}$ \\
\hline & WPICH & 140 & $76.2^{\mathrm{Aa}}$ & $82.6^{\mathrm{Aa}}$ & $79.9^{\mathrm{Ba}}$ & $56.6^{\mathrm{Bb}}$ & $45.9^{\mathrm{Cc}}$ & $64.6^{\mathrm{Ab}}$ & $64.8^{\mathrm{Ab}}$ & $64.8^{\mathrm{Ab}}$ & $64.9^{\mathrm{Ab}}$ \\
\hline & WPICH & 210 & $65.2^{\mathrm{Bb}}$ & $76.3^{\mathrm{ABa}}$ & $72.9^{\mathrm{Bab}}$ & $65.4^{\mathrm{ABb}}$ & $51.9^{\mathrm{BCc}}$ & $72.2^{\mathrm{Aab}}$ & $72.3^{\text {Aab }}$ & $72.1^{\mathrm{Aab}}$ & $72.2^{\text {Aab }}$ \\
\hline \multirow[t]{4}{*}{ With CU } & WPICU & 140 & $3.3^{\mathrm{d}}$ & $3.3^{\mathrm{Bd}}$ & $8.1^{\mathrm{Bc}}$ & $13.5^{\mathrm{Aa}}$ & $9.4^{\mathrm{BCb}}$ & $10.4^{\mathrm{Bb}}$ & $10.1^{\mathrm{Bb}}$ & $10.3^{\mathrm{Bb}}$ & $10.1^{\mathrm{Bb}}$ \\
\hline & WPICU & 210 & $2.7^{\mathrm{e}}$ & $3.1^{\mathrm{Be}}$ & $6.7^{\mathrm{Cd}}$ & $10.8^{\mathrm{Ba}}$ & $8.4^{\mathrm{Cbc}}$ & $8.9^{\mathrm{Cbc}}$ & $8.8^{\mathrm{Cbc}}$ & $9.2^{\mathrm{Bb}}$ & $8.8^{\mathrm{Cbc}}$ \\
\hline & WPICUCH & 140 & $3.0^{\mathrm{c}}$ & $6.6^{\mathrm{Ab}}$ & $10.0^{\mathrm{Aa}}$ & $7.7^{\mathrm{Db}}$ & $10.3^{\mathrm{Ba}}$ & $10.7^{\mathrm{Ba}}$ & $10.6^{\mathrm{Ba}}$ & $10.2^{\mathrm{Ba}}$ & $10.1^{\mathrm{Ba}}$ \\
\hline & WPICUCH & 210 & $3.2^{\mathrm{e}}$ & $7.2^{\mathrm{Ad}}$ & $10.8^{\mathrm{Ab}}$ & $9.4^{\mathrm{Cc}}$ & $12.2^{\mathrm{Aa}}$ & $12.1^{\mathrm{Aab}}$ & $12.0^{\mathrm{Aab}}$ & $11.9^{\text {Aab }}$ & $12.3^{\mathrm{Aa}}$ \\
\hline
\end{tabular}


Note: Control, 676.5; Trolox (20 mM), 12.1.

WPI: whey protein isolate, $\mathrm{CU}$ : curcumin, $\mathrm{CH}$ : casein hydrolysate.

For treatments without or with CU significant differences within each row (lowercase) or each column (uppercase) are indicated by different letters $(\mathrm{P}<0.05)$.

RLU values increased until 12 days of storage, indicating decreased antioxidant persistence (Table 6). After $12 \mathrm{~d}$ of storage (Table 6), AP decreased until $28 \mathrm{~d}$ of storage but was still greater than the AP after $2 \mathrm{~d}$ of storage. When averaged over storage time, inclusion of $\mathrm{CH}$ increased AA and AP at $210 \mathrm{MPA}(\mathrm{P}<0.05)$ but did not impact AA and AP at $140 \mathrm{MPa}(\mathrm{P}>0.05)$. This may have occurred due to heat generation at $210 \mathrm{MPa}$ that could have led to decreased antioxidant activity as evidenced in Sun et al. (2019) that heat treatment of curcuminoids led to a decrease in antioxidant activity. When means were separated based on treatment $\times$ pressure $\times$ time storage time, no differences existed in AA ( $>0.05)$ between treatments at d 0 (Table 5). After $2 \mathrm{~d}$ of storage, the WPICU treatments at 140 and $210 \mathrm{MPa}$ had less AA $(\mathrm{P}<0.05)$ than the WPICUCH treatments at 140 and 210 $\mathrm{MPa}$, indicating that the addition of $\mathrm{CH}$ rapidly decreases antioxidant capacity in comparison to $\mathrm{CU}$ alone. After $4 \mathrm{~d}$ of storage, the WPICUCH treatments at $140 \mathrm{MPa}$ had greater AA $(\mathrm{P}<0.05)$ than the WPICU treatment at 210 $\mathrm{MPa}$, and the WPICUCH treatment at $210 \mathrm{MPa}$ had greater AA than WPICU treatment at both 140 and $210 \mathrm{MPa}$ (Table 5). Though the $210 \mathrm{MPa}$ treatments provided the greatest emulsion stability in the WPICUCH treatment, its antioxidant activity was not as great as the WPICUCH treatment at $140 \mathrm{MPa}$ and WPICU treatments at both pressures throughout the storage time of the emulsions. Similar to AA, there were no differences in AP $(\mathrm{P}<0.05)$ among treatments at $\mathrm{d} 0$ (Table 5). After $2 \mathrm{~d}$ of storage, AP was greater $(\mathrm{P}<0.05)$ in WPICU than WPICUCH at $210 \mathrm{MPa}$ (Table 6). After $4 \mathrm{~d}$ of storage, AP was greater $(\mathrm{P}<0.05)$ at WPICU and $210 \mathrm{MPa}$ than the other treatment and pressure combinations. WPICUCH at $140 \mathrm{MPa}$ had greater AP $(\mathrm{P}<0.05)$ after $8 \mathrm{~d}$ of storage than WPICU at $140 \mathrm{MPa}$ and WPICUCH at $210 \mathrm{MPa}$. In addition, WPICU at $210 \mathrm{MPa}$ had greater AP $(\mathrm{P}<0.05)$ than WPICU after 8 days of storage. The WPICUCH treatment at $210 \mathrm{MPa}$ had the least AP out of any treatments, and the WPICUCH treatment at $140 \mathrm{MPa}$ was less persistent $(\mathrm{P}<0.05)$ than the WPICU at either 140 or $210 \mathrm{MPa}$ after 12 days of storage. By day 16, no differences existed in $\mathrm{AP}(\mathrm{P}>0.05)$ among treatments, a result that stayed consistent through the rest of the $28 \mathrm{~d}$ storage period.

Table 6. Mean antioxidant persistence (relative light unit, RLU) of the WPI (1\%), tween 20 (20\% of WPI), peanut oil $(\Phi=0.05)$, and/or casein hydrolysate $(2 \%$ of WPI) formulated nano-vesicular vehicles and curcumin loaded vesicular vehicles that were subjected to 140 and $210 \mathrm{MPa}$ of homogenization (single pass) over 28 days of storage

\begin{tabular}{|c|c|c|c|c|c|c|c|c|c|c|c|}
\hline Treatment & & Pressure $(\mathrm{MPa})$ & Day 0 & Day 2 & Day 4 & Day 8 & Day 12 & Day 16 & Day 20 & Day 24 & Day 28 \\
\hline \multirow[t]{4}{*}{ Without CU } & WPI & 140 & $61.1^{\mathrm{ABb}}$ & $54.7^{\mathrm{Bb}}$ & $76.7^{\mathrm{Aa}}$ & $60.3^{\mathrm{Ab}}$ & $62.0^{\mathrm{Ab}}$ & $55.7^{\mathrm{ABb}}$ & $55.2^{\mathrm{ABb}}$ & $55.4^{\mathrm{ABb}}$ & $55.7^{\mathrm{ABb}}$ \\
\hline & WPI & 210 & $57.3^{\mathrm{Bb}}$ & $56.0^{\mathrm{Bb}}$ & $67.8^{\mathrm{Ba}}$ & $64.7^{\mathrm{Aa}}$ & $52.2^{\mathrm{Bc}}$ & $48.6^{\mathrm{Bc}}$ & $49.8^{\mathrm{Bc}}$ & $49.8^{\mathrm{Bc}}$ & $49.9^{\mathrm{Bc}}$ \\
\hline & WPICH & 140 & $65.8^{\mathrm{Aa}}$ & $69.5^{\mathrm{Aa}}$ & $66.4^{\mathrm{BCa}}$ & $47.9^{\mathrm{Bc}}$ & $50.0^{\mathrm{Ab}}$ & $52.6^{\mathrm{ABbc}}$ & $52.5^{\mathrm{Bbc}}$ & $52.6^{\mathrm{Bbc}}$ & $53.1^{\mathrm{ABbc}}$ \\
\hline & WPICH & 210 & $54.9^{\mathrm{B}}$ & $61.7^{\mathrm{AB}}$ & $59.7^{\mathrm{C}}$ & $58.7^{\mathrm{A}}$ & $60.0^{\mathrm{AB}}$ & $60.0^{\mathrm{A}}$ & $61.0^{\mathrm{A}}$ & $62.0^{\mathrm{A}}$ & $61.0^{\mathrm{A}}$ \\
\hline \multirow[t]{4}{*}{ With CU } & WPICU & 140 & $3.4^{\mathrm{d}}$ & $3.5^{\mathrm{Bd}}$ & $9.0^{\mathrm{Ab}}$ & $10.8^{\mathrm{Aa}}$ & $7.1^{\mathrm{Cc}}$ & $7.8^{\mathrm{Bc}}$ & $7.7^{\mathrm{Bc}}$ & $7.9^{\mathrm{ABbc}}$ & $7.9^{\mathrm{bc}}$ \\
\hline & WPICU & 210 & $2.6^{\mathrm{c}}$ & $2.8^{\mathrm{Bc}}$ & $6.0^{\mathrm{Bb}}$ & $8.1^{\mathrm{Ba}}$ & $7.1^{\mathrm{Ca}}$ & $7.2^{\mathrm{Ba}}$ & $7.3^{\mathrm{Ba}}$ & $7.3^{\mathrm{Ba}}$ & $7.4^{\mathrm{a}}$ \\
\hline & WPICUCH & 140 & $2.9^{\mathrm{e}}$ & $4.6^{\mathrm{Ad}}$ & $9.8^{\mathrm{Aa}}$ & $6.3^{\mathrm{Cc}}$ & $10.8^{\mathrm{Ba}}$ & $8.3^{\mathrm{Ab}}$ & $8.1^{\mathrm{ABb}}$ & $7.2^{\mathrm{Bbc}}$ & $7.5^{\mathrm{b}}$ \\
\hline & WPICUCH & 210 & $2.9^{\mathrm{e}}$ & $5.6^{\mathrm{Ad}}$ & $8.7^{\mathrm{Abc}}$ & $9.8^{\mathrm{Ab}}$ & $13.9^{\mathrm{Aa}}$ & $9.0^{\mathrm{Ab}}$ & $9.1^{\mathrm{Ab}}$ & $8.9^{\mathrm{Ab}}$ & $7.8^{\mathrm{c}}$ \\
\hline
\end{tabular}

Note: Control, 1024.9; Trolox (20 mM), 13.7.

WPI: whey protein isolate, $\mathrm{CU}$ : curcumin, $\mathrm{CH}$ : casein hydrolysate.

For treatments without or with CU significant differences within each row (lowercase) or each column (uppercase) are indicated by different letters $(\mathrm{P}<0.05)$.

Even though the treatments without CU had much less AA and AP than the treatments with CU, the WPI and WPICH treatments ranged between 40 to 100, which was much less than the RLU of 600 for the control samples. This indicates that the whey protein and casein hydrolysate still functioned as antioxidants in the emulsion system. The CU molecule ((1,7-bis(4-hydroxy-3-methoxyphenyl)-1,6-heptdiene-3,5-dione) exists in the enolate form at the $\mathrm{pH}$ of this study which allows the donation of a hydrogen atom in polar solvents. Moreover, it can readily transfer electrons and donate $\mathrm{H}+$ atoms from its phenolic sites (Barzegar and Moosavi-Movahedi, 2011). $\mathrm{AA}$ and $\mathrm{AP}$ of the NVV + CU were stable and preserved throughout storage when compared to the coarse emulsion (3.4 at $0 \mathrm{~d}$ and 23.5 at $28 \mathrm{~d}$ ). It is possible that covalent attachment to the nucleophilic residues of whey proteins occurred in the intense cavitation environment during UHPH, which led to enhanced stability due to a synergistic relationship between $\mathrm{CU}$ and other components that have been reported previously (Hewlings et al., 2017). CU has three reactive groups that include one diketone moiety (the linker region), and two phenolic 
groups that lead to its high antioxidant effectiveness and persistence (Priyadarsini, 2013).

\subsection{Surface Morphology of Transmission Electron Micrograph (TEM)}

The images obtained by TEM showed distinct visual differences. Surface morphology (Fig. 1a) of the dried emulsion with WPICH at $140 \mathrm{MPa}$ of $83 \mu \mathrm{m}$ globular diameter exhibited small-size $(2-3 \mu \mathrm{m})$ ovular pores when compared to larger pores in the $210 \mathrm{MPa}$ treated samples with globular diameter of $205 \mu \mathrm{m}$ (Fig. 1b). Surface morphology of the emulsion with WPICU (Fig. 1c) at $140 \mathrm{MPa}$ with globular size of $213 \mu \mathrm{m}$ indicated a few cracked fissures with the rest of the surface granular in appearance. The immiscible curcumin particle after dehydration produce rough surface and dehydration process created cracked appearance to facilitate the evaporation process. This result is consistent with the study that also showed similar ovular cracked surface after dehydration (Ahmed et al. 2019). The same feature was observed in the sample with $210 \mathrm{MPa}(178 \mu \mathrm{m})$ but with less consistency in emulsion structure (Fig. 1d). This change of consistency was attributed due to change in globule size of the emulsion (decrease in mean diameter of the globule). Surface morphology of the WPICHCU sample at $140 \mathrm{MPa}$ with globule droplet size of $169 \mu \mathrm{m}$ exhibited smooth gelling after drying (Fig. 1e). However, the $210 \mathrm{MPa}$ treatment $(162 \mu \mathrm{m})$ decreased the emulsion consistency as high pressure treatment imparted coalescence effect (Fig. 1f) which was also observed in previous investigations of TEM images (Abbas et al., 2015).

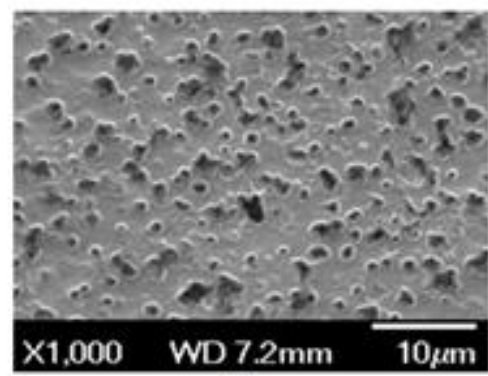

(a)

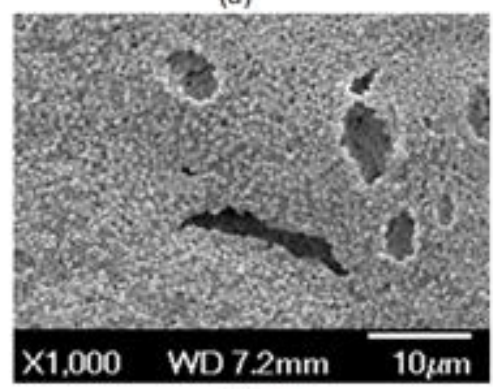

(c)

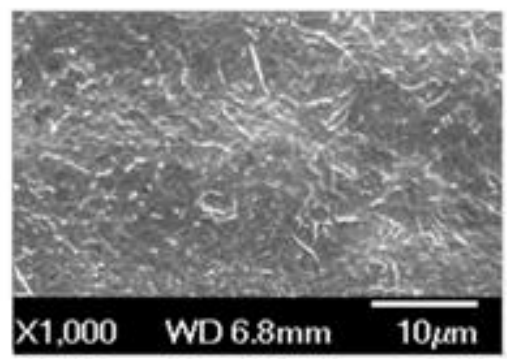

(e)

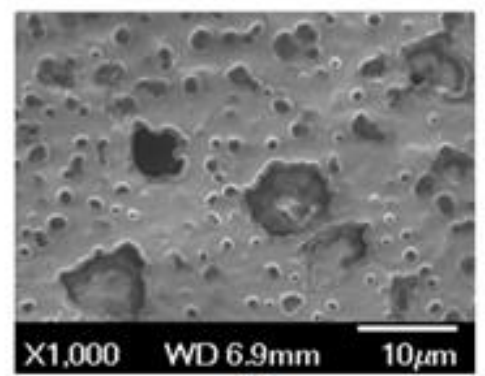

(b)

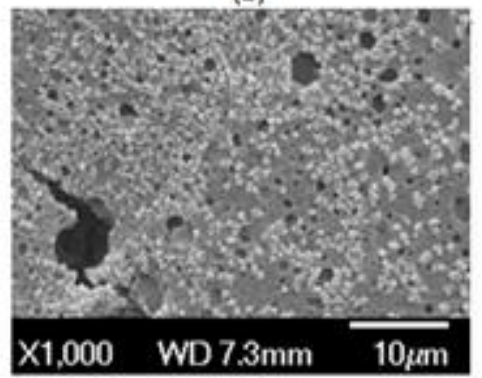

(d)

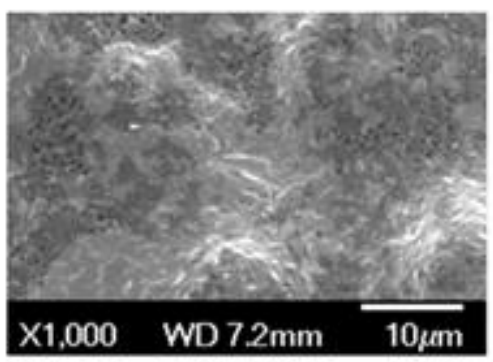

(f)

Figure 1. Transmission Electron Microscopy of the following treatments: (a) WPICH at $140 \mathrm{MPa}$; (b) WPICH at $210 \mathrm{MPa}$; (c) WPICU at $140 \mathrm{MPa}$; (d) WPICU at $210 \mathrm{MPa}$; (e) WPICUCH at $140 \mathrm{MPa}$; (f) WPICUCH at 210 $\mathrm{MPa}$

\section{Conclusions}

Use of $\mathrm{CH}$ and the pressure of $210 \mathrm{MPa}$ led to the most stable emulsions over storage time. Therefore, the WPICH system, namely the NVV system in this study, can deliver bioactive ingredients such as CU. In this 
NVV system, the incorporation of CU remained stable as well as preserved the AA and AP of CU over 28 days of storage. Thus whey protein isolate, tween 20 , casein hydrolysate can effectively stabilize NVV and effectively deliver bioactive curcumin. Further research needs to be conducted in a beverage application to determine the emulsion stability and antioxidant properties in real world applications.

\section{Acknowledgements}

The authors would like to thank Dr. Sam Chang for allowing to use the equipment at Mississippi State University and Dr. I-Wei Chu from the Institute for Imaging and Analytical Technologies at Mississippi State University for her support on Transmission Electron Microscopy images of emulsions. This research did not receive any specific grant from funding agencies in the public, commercial, or not-for-profit sectors.

\section{References}

Abbas, S., Karangwa, E., Bashari, M., Hayat, K., Hong, X., Sharif, H. R., \& Zhang, X. (2015). Fabrication of polymeric nanocapsules from curcumin-loaded nanoemulsion templates by self-assembly. Ultrasonics Sonochemistry, 23, 81-92. https://doi.org/10.1016/j.ultsonch.2014.10.006

Aditya, N. P., Hamilton, I. E., \& Norton, I. T. (2017). Amorphous nano-curcumin stabilized oil in water emulsion: Physico chemical characterization. Food Chemistry, 224, 191-200. https://doi.org/10.1016/j.foodchem.2016.12.082

Adjonu, R., Doran, G., Torley, P., \& Agboola, S. (2014). Whey protein peptides as components of nanoemulsions: A review of emulsifying and biological functionalities. Journal of Food Engineering, 122, 15-27. https://doi.org/10.1016/j.jfoodeng.2013.08.034

Aggarwal, B. B., Kumar, A., \& Bharti, A. C. (2003). Anticancer potential of curcumin: preclinical and clinical studies. Anticancer Research, 23(1/A), 363-398.

Ahmad, N., Ahmad, R., Al-Qudaihi, A., Alaseel, S. E., Fita, I. Z., Khalid, M. S., \& Pottoo, F. H. (2019). Preparation of a novel curcumin nanoemulsion by ultrasonication and its comparative effects in wound healing and the treatment of inflammation. RSC advances, 9(35), 20192-20206. https://doi.org/10.1039/C9RA03102B

Ahmed, K., Li, Y., McClements, D. J., \& Xiao, H. (2012). Nanoemulsion-and emulsiobased delivery systems for curcumin: encapsulation and release properties. Food Chemistry, 132(2), 799-807. https://doi.org/10.1016/j.foodchem.2011.11.039

Alizadeh, A. M., Khaniki, M., Azizian, S., Mohaghgheghi, M. A., Sadeghizadeh, M., \& Najafi, F. (2012). Chemoprevention of azoxymethane-initiated colon cancer in rat by using a novel polymeric nanocarrier-curcumin. European Journal of Pharmacology, 689(1), 226-232. https://doi.org/10.1016/j.ejphar.2012.06.016

Barzegar, A., \& Moosavi-Movahedi, A. A. (2011). Intracellular ROS protection efficiency and free radical-scavenging activity of curcumin. PLoS One, 6(10), e26012.

https://doi.org/10.1371/journal.pone.0026012

Basumallick, S., Gabriela Nogueira Campos, M., Richardson, D., Gesquiere, A., \& Santra, S. (2016). Hydrothermally treated chitosan spontaneously forms water-soluble spherical particles stable at a wide $\mathrm{pH}$ range. International Journal of Polymeric Materials and Polymeric Biomaterials, 65(15), 751-758. https://doi.org/10.1080/00914037.2016.1163568

Calligaris, S., Plazzotta, S., Bot, F., Grasselli, S., Malchiodi, A., \& Anese, M. (2016). Nanoemulsion preparation by combining high pressure homogenization and high power ultrasound at low energy densities. Food Research International, 83, 25-30. https://doi.org/10.1016/j.foodres.2016.01.033

Chanamai, R. A. D. J. M., \& McClements, D. J. (2002). Comparison of gum arabic, modified starch, and whey protein isolate as emulsifiers: influence of $\mathrm{pH}, \mathrm{CaCl}_{2}$ and temperature. Journal of Food Science, 67(1), 120-125. https://doi.org/10.1111/j.1365-2621.2002.tb11370.x

Chainani-Wu, N. (2003). Safety and anti-inflammatory activity of curcumin: a component of tumeric (Curcuma longa). The Journal of Alternative \& Complementary Medicine, 9(1), 161-168. https://doi.org/10.1089/107555303321223035

Chin, D., Hagl, S., Hoehn, A., Huebbe, P., Pallauf, K., Grune, T., \& Rimbach, G. (2014). Adenosine triphosphate concentrations are higher in the brain of APOE3-compared to APOE4-targeted replacement mice and can be modulated by curcumin. Genes \& Nutrition, 9(3), 397. https://doi.org/10.1007/s12263-014-0397-3 
Davis, J. P., Doucet, D., \& Foegeding, E. A. (2005). Foaming and interfacial properties of hydrolyzed $\beta$-lactoglobulin. Journal of Colloid and Interface Science, 288(2), 412-422. https://doi.org/10.1016/j.jcis.2005.03.002

De, R., Kundu, P., Swarnakar, S., Ramamurthy, T., Chowdhury, A., Nair, G. B., \& Mukhopadhyay, A. K. (2009). Antimicrobial activity of curcumin against Helicobacter pylori isolates from India and during infections in mice. Antimicrobial Agents and Chemotherapy, 53(4), 1592-1597. https://doi.org/10.1128/AAC.01242-08

Destribats, M., Gineste, S., Laurichesse, E., Tanner, H., Leal-Calderon, F., Héroguez, V., \& Schmitt, V. (2014). Pickering emulsions: what are the main parameters determining the emulsion type and interfacial properties? Langmuir, 30(31), 9313-9326. https://doi.org/10.1021/la501299u

Dhillon, N., Aggarwal, B. B., Newman, R. A., Wolff, R. A., Kunnumakkara, A. B., Abbruzzese, J. L., Ng, C. S., Badmaev, V., \& Kurzrock, R. (2008). Phase II trial of curcumin in patients with advanced pancreatic cancer. Clinical Cancer Research, 14(14), 4491-4499. 10.1158/1078-0432.CCR-08-0024

Donsì, F., Annunziata, M., Vincensi, M., \& Ferrari, G. (2012). Design of nanoemulsion-based delivery systems of natural antimicrobials: effect of the emulsifier. Journal of Biotechnology, 159(4), 342-350. https://doi.org/10.1016/j.jbiotec.2011.07.001

Euston, S. R., Finnigan, S. R., \& Hirst, R. L. (2002). Kinetics of droplet aggregation in heated whey protein-stabilized emulsions: effect of polysaccharides. Food Hydrocolloids, 16(5), 499-505. https://doi.org/10.1016/S0268-005X(01)00130-8

Fan, Y., Yi, J., Zhang, Y., Wen, Z., \& Zhao, L. (2017). Physicochemical stability and in vitro bioaccessibility of $\beta$-carotene nanoemulsions stabilized with whey protein-dextran conjugates. Food Hydrocolloids, 63, 256-264. https://doi.org/10.1016/j.foodhyd.2016.09.008

Gauthier, S. F., \& Pouliot, Y. (2003). Functional and biological properties of peptides obtained by enzymatic hydrolysis of whey proteins. Journal of Dairy Science, 86, E78-E87. https://doi.org/10.3168/jds.S0022-0302(03)74041-7

Gutiérrez, J. M., González, C., Maestro, A., Sole, I., Pey, C. M., \& Nolla, J. (2008). Nano-emulsions: New applications and optimization of their preparation. Current Opinion in Colloid \& Interface Science, 13(4), 245-251. https://doi.org/10.1016/j.cocis.2008.01.005

Haque, Z. Z., Mukherjee, D., Mukherjee, S., \& Chang, S. (2013). Antioxidative Activity and Resilience of Cheddar and Edam Whey as Determined from Total Radical Trapping Potentials (TRAP). Journal of Animal Science, 91(E-Suppl. 2), 626.

He, W., Tan, Y., Tian, Z., Chen, L., Hu, F., \& Wu, W. (2011). Food protein-stabilized nanoemulsions as potential delivery systems for poorly water-soluble drugs: preparation, in vitro characterization, and pharmacokinetics in rats. International journal of nanomedicine, 6, 521. https://doi.org/10.2147/IJN.S17282

Hewlings, S. J., \& Kalman, D. S. (2017). Curcumin: a review of its effects on human health. Foods, 6(10), 92. https://doi.org/10.3390/foods6100092

Hu, J. N., Zheng, H., Chen, X. X., Li, X., Xu, Y., \& Xu, M. F. (2020). Synergetic effects of whey protein isolate and naringin on physical and oxidative stability of oil-in-water emulsions. Food Hydrocolloids, 101, 105517. https://doi.org/10.1016/j.foodhyd.2019.105517

Hua, C., Yu, W., Yang, M., Cai, Q., Gao, T., Zhang, S., ... Liu, Y. (2021). Casein-pectin nanocomplexes as a potential oral delivery system for improving stability and bioactivity of curcumin. Colloid and Polymer Science, 1-10. https://doi.org/10.1007/s00396-021-04858-x

Hunter, R. J. (2013). Zeta potential in colloid science: principles and applications (Vol. 2). p. 59-69.

Kentish, S., Wooster, T. J., Ashokkumar, M., Balachandran, S., Mawson, R., \& Simons, L. (2008). The use of ultrasonics for nanoemulsion preparation. Innovative Food Science \& Emerging Technologies, 9(2), 170-175. https://doi.org/10.1016/j.ifset.2007.07.005

Kwak, H. S., Choi, S. S., Ahn, J., \& Lee, S. W. (2002). Casein hydrolysate fractions act as emulsifiers in process cheese. Journal of Food Science, 67(2), 821-825. https://doi.org/10.1111/j.1365-2621.2002.tb10684.x

Li, M., Ma, Y., \& Cui, J. (2014). Whey-protein-stabilized nanoemulsions as a potential delivery system for water-insoluble curcumin. LWT-Food science and technology, 59(1), 49-58.

https://doi.org/10.1016/j.lwt.2014.04.054 
Lissi, E., Salim-Hanna, M., Pascual, C., \& del Castillo, M. D. (1995). Evaluation of total antioxidant potential (TRAP) and total antioxidant reactivity from luminol-enhanced chemiluminescence measurements. Free Radical Biology and Medicine, 18(2), 153-158. https://doi.org/10.1016/0891-5849(94)00117-3

Lovelyn, C., \& Attama, A. A. (2011). Current state of nanoemulsions in drug delivery. Journal of Biomaterials and Nanobiotechnology, 2(5), 626. https://doi.org/10.4236/jbnb.2011.225075

Maali, A., \& Mosavian, M. H. (2013). Preparation and application of nanoemulsions in the last decade (2000-2010). Journal of Dispersion Science and Technology, 34(1), 92-105. https://doi.org/10.1080/01932691.2011.648498

McClements, D. J. (2005). Theoretical analysis of factors affecting the formation and stability of multilayered colloidal dispersions. Langmuir, 2l(21), 9777-9785. https://doi.org/10.1021/la0512603

Midekessa, G., Godakumara, K., Ord, J., Viil, J., Lättekivi, F., Dissanayake, K., ... Fazeli, A. (2020). Zeta potential of extracellular vesicles: toward understanding the attributes that determine colloidal stability. Acs Omega, 5(27), 16701-16710. https://doi.org/10.1021/acsomega.0c01582

Mukherjee, S., Schilling, M. W., Zhang, X., \& Haque, Z. Z. (2019). Stabilized emulsion system formulated with whey protein isolate, hexanoic acid, casein hydrolysate, chitosan, lecithin, and $\mathrm{NaCl}$. Annals Food Science and Technology, 20(3), 451-459.

Nelson, K. M., Dahlin, J. L., Bisson, J., Graham, J., Pauli, G. F., \& Walters, M. A. (2017). The essential medicinal chemistry of curcumin: miniperspective. Journal of Medicinal Chemistry, 60(5), 1620-1637. https://doi.org/10.1021/acs.jmedchem.6b00975

O'Regan, J., \& Mulvihill, D. M. (2010). Sodium caseinate-maltodextrin conjugate stabilized double emulsions: Encapsulation and stability. Food Research International, 43(1), 224-231. https://doi.org/10.1016/j.foodres.2009.09.031

Pascual-Pineda, L. A., Flores-Andrade, E., Jiménez-Fernández, M., \& Beristain, C. I. (2015). Kinetic and thermodynamic stability of paprika nanoemulsions. International Journal of Food Science \& Technology, 50(5), 1174-1181. https://doi.org/10.1111/ijfs.12750

Paunov, V. N., Cayre, O. J., Noble, P. F., Stoyanov, S. D., Velikov, K. P., \& Golding, M. (2007). Emulsions stabilised by food colloid particles: Role of particle adsorption and wettability at the liquid interface. Journal of Colloid and Interface Science, 312(2), 381-389. https://doi.org/10.1016/j.jcis.2007.03.031

Priyadarsini, K. (2014). The chemistry of curcumin: from extraction to therapeutic agent. Molecules, 19(12), 20091-20112. https://doi.org/10.3390/molecules191220091

Ramos, Ó. L., Fernandes, J. C., Silva, S. I., Pintado, M. E., \& Malcata, F. X. (2012). Edible films and coatings from whey proteins: a review on formulation, and on mechanical and bioactive properties. Critical Reviews in Food Science and Nutrition, 52(6), 533-552. https://doi.org/10.1080/10408398.2010.500528

Riddick, T. M. (1968). Control of colloid stability through zeta potential: with a closing chapter on its relationship to cardiovascular disease (No. 541.3453). Published for Zeta-Meter, inc., by Livingston Pub. Co.

Sharma, O. P. (1976). Antioxidant activity of curcumin and related compounds. Biochemical Pharmacology, 25(15), 1811. https://doi.org/10.1016/0006-2952(76)90421-4

Shetty, D., Kim, Y. J., Shim, H., \& Snyder, J. P. (2015). Eliminating the heart from the curcumin molecule: monocarbonyl curcumin mimics (MACs). Molecules, 20(1), 249-292. https://doi.org/10.3390/molecules20010249

Sjöblom, J., Mingyuan, L., Christy, A. A., \& Gu, T. (1992). Water-in-crude-oil emulsions from the Norwegian continental shelf 7. Interfacial pressure and emulsion stability. Colloids and Surfaces, 66(1), 55-62. https://doi.org/10.1016/0166-6622(92)80120-Q

Souguir, H., Salaün, F., Douillet, P., Vroman, I., \& Chatterjee, S. (2013). Nanoencapsulation of curcumin in polyurethane and polyurea shells by an emulsion diffusion method. Chemical Engineering Journal, 221, 133-145. https://doi.org/10.1016/j.cej.2013.01.069

Su, D., \& Zhong, Q. (2016). Formation of thymol nanoemulsions with combinations of casein hydrolysates and sucrose stearate. Journal of Food Engineering, 179, 1-10. https://doi.org/10.1016/j.jfoodeng.2016.01.030 
Sun, J. L., Ji, H. F., \& Shen, L. (2019). Impact of cooking on the antioxidant activity of spice turmeric. Food \& Nutrition Research, 63, 3451. https://doi.org/10.29219/fnr.v63.3451

Tirok, S., Scherze, I., \& Muschiolik, G. (2001). Behaviour of formula emulsions containing hydrolysed whey protein and various lecithins. Colloids and Surfaces B: Biointerfaces, 21(1), 149-162. https://doi.org/10.1016/S0927-7765(01)00168-0

Tsai, Y. M., Chien, C. F., Lin, L. C., \& Tsai, T. H. (2011). Curcumin and its nano-formulation: the kinetics of tissue distribution and blood-brain barrier penetration. International Journal of Pharmaceutics, 416(1), 331-338. https://doi.org/10.1016/j.ijpharm.2011.06.030

Van de Ven, H., Vermeersch, M., Matheeussen, A., Vandervoort, J., Weyenberg, W., Apers, S., ... Ludwig, A. (2011). PLGA nanoparticles loaded with the antileishmanial saponin $\beta$-aescin: Factor influence study and in vitro efficacy evaluation. International Journal of Pharmaceutics, 420(1), 122-132. https://doi.org/10.1016/j.ijpharm.2011.08.016

Yu, H., \& Huang, Q. (2010). Enhanced in vitro anti-cancer activity of curcumin encapsulated in hydrophobically modified starch. Food Chemistry, 119(2), 669-674. https://doi.org/10.1016/j.foodchem.2009.07.018

Zhao, Q., Miriyala, N., Su, Y., Chen, W., Gao, X., Shao, L., Yan, R., Li, H., Yao, X., Cao, D., Wang, Y., \& Ouyang, D. (2018). Computer-aided formulation design for a highly soluble lutein-cyclodextrin multiple-component delivery system. Molecular Pharmaceutics, 15(4), 1664-1673. https://doi.org/10.1021/acs.molpharmaceut.8b00056

Zou, L., Liu, W., Liu, C., Xiao, H., \& McClements, D. J. (2015). Utilizing food matrix effects to enhance nutraceutical bioavailability: increase of curcumin bioaccessibility using excipient emulsions. Journal of Agricultural and Food Chemistry, 63(7), 2052-2062. https://doi.org/10.1021/jf506149f

\section{Copyrights}

Copyright for this article is retained by the author(s), with first publication rights granted to the journal.

This is an open-access article distributed under the terms and conditions of the Creative Commons Attribution license (http://creativecommons.org/licenses/by/4.0/). 